\title{
Nikah di bawah tangan perspektif yuridis dan sosiologis
}

\author{
Munir Subarman \\ Fakultas Syariah Institut Agama Islam Negeri (LAIN) Syekh Nurjati Cirebon \\ e-mail:munir.subarman@yahoo.com
}

The purpose of this paper is to determine the implementation of unregistered marriages and its obstacles in social life. The author uses a qualitative approach with descriptive methode which describes systematically, factual, and accurate information on the facts, properties and relationships among actualized phenomena. Siri marriage is a marriage conducted in accordance with terms and pillars of marriage in Islam, but not with the Registrar of Marriage Officer (VAT). Unregistered marriages is considered legitimate according to religion. Eventhough it causes problems because it is not listed in state law. So it will have difficulty regarding divorce and division of matrimonial property, as well as an impact on the status of children, guardianship status of marriage rights, and inheritance rights.

Tujuan penulisan ini untuk mengetahui dalam pelaksanaan nikah siri dan kendala-kendala dalam kehidupan sosialnya. Penulis menggunakan pendekatan kualitatif dan dari segi sifatnya tulisan ini bersifat deskriptif yaitu analisis yang mengambarkan atau melukiskan secara sistematis, faktual, dan akurat mengenai fakta-fakta, sifat-sifat serta hubungan antar fenomena yang diaktualisasikan. Nikah siri merupakan pernikahan yang dilaksanakan sesuai dengan syarat dan rukun nikah dalam Islam, tetapi tidak oleh Petugas Pencatat Nikah (PPN). Nikah siri dipandang sah menurut agama, menimbulkan banyak masalah, karena pernikahannya tidak tercatat secara hukum negara. Jadi akan mengalami kesulitan mengenai perceraian dan pembagian harta bersama, serta berdampak terhadap status anak, hak status perwalian nikah, dan hak waris.

Keywords: Marriage; Unregistered marriages; Jurisprudence; Sosiological perspective

\section{Pendahuluan}

Pernikahan bukan hanya merupakan masalah sosial yang memiliki aspek sosiologis, tetapi juga terkait dengan konteks budaya dan pemahaman agama. Oleh karena itu, pernikahan adalah suatu lembaga sosial sekaligus lembaga keagamaan. Pernikahan merupakan sunnatullah 
ljtihad, Jurnal Wacana Hukum Islam dan Kemanusiaan, Volume 13, No. 1, Juni 2013:65-83

yang mengatur tata kehidupan manusia, baik perorangan maupun kelompok. Dilihat dari sisi sosiologis, pernikahan adalah suatu bentuk kerjasama kehidupan antara pria dan wanita dalam kehidupan suatu masyarakat di bawah suatu peraturan khas (khusus) yang memiliki ciri-ciri tertentu, yaitu pria bertindak sebagai suami, dan perempuan bertindak sebagai istri, yang keduanya dalam ikatan yang sah (Kartasapoetra, 1997:76-78). Dengan pernikahan yang sah pergaulan laki-laki dan perempuan dipandang terhormat sebagai manusia yang beradab. Dalam Islam pernikahan tidak semata-mata sebagai kontrak keperdataan biasa (BW/KUH Perdaa Pasal 26), tetapi mempunyai nilai ibadah (Kompilasi Hukum Islam Pasal 2).

Al-Qur'an telah memandang tali pernikahan itu sebagai ikatan yang kokoh, atau perjanjian yang kokoh (mìthaq ghalida) (QS. al-Nisa : 21; Q.S. al-Ahzāb: 7. Q.S. al-Nisā': 154). Pernikahan sebagai interaksi sosisa antar individu dan masyarakat yang bernilai ibadah, juga sebagai perbuatan hukum, jika pernikahan itu dilakukan menurut ketentuan hukum yang berlaku (UU. No. 1 Tahun 1974. Pasal 1).

Salah satu bentuk pernikahan yang kontroversial dibicarakan adalah nikah di bawah tangan. Mayoritas masyarakat meyakini, bahwa nikah di bawab tangan secara syar'i adalah sah menurut ajaran Islam, namun realitas menunjukan banyaknya pernikahan di bawah tangan yang berdampak negatif dan kesengsaraan bagi perempuan, karena pernikahan di bawah tangan itu seringkali dijadikan 'dalih' bagi laki-laki untuk bertindak sewenang-wenang terhadap pasangannya baik secara psikologis maupun material. Pembahasan dalam jurnal ini akan membedah eksistensi pernikahan di bawah tangan ditinjau dari perspektif yuridis dan sosiologis.

Karya ini menggunakan pradigma sosiologis, karena permasalahan yang dibahas menyangkut struktur sosial (social structure) dan institusi sosial (social institution). Pembahasan ini menyangkut pola pikir dan gaya hidup masyarakat dalam menyikapi perkawinan dan perceraian di bawah tangan dalam hubungan dengan fakta social. Teori sosial yang dipergunakan adalah teori fungsionalisme struktural. Sedangkan teori hukum yang dipergunakan sebagai acuan adalah teori social engineerring (Rahardjo, 1997: 66).

\section{Nikah dalam prespektif yuridis}

Secara bahasa, nikah bermakna "al-'ammu wa al-wa'yu" yang berarti berkumpul dan bersetubuh atau 'ibäratun 'an al-wa'i wa al-'aqdi jam'an (al-Zuhaili, 1991: 29). Kata lain dari nikah adalah al- 
tazwij. Dalam hal ini al-Qur'an menggunakan kata nikah 23 kali, yang berarti berhimpun, dan zawwaja 80 kali, berarti berpasangan (al-Zuhaili, 1991: 31). Dengan demikian, secara etimologi pernikahan berarti berkumpul dan berpasangan dua insan yang semula hidup sendiri, menjadi satu kesatuan dalam wadah keluarga.

Menurut istilah fikih nikah adalah: akad yang mengandung kebolehan untuk bersetubuh dengan lafadz inkaha atau tazwij. Definisi nikah tidak terdapat perbedaan prinsipil di kalangan ulama-ulama fikih, yang ada hanya perbedaan redaksi saja. (al-Jazairy, J. IV, t.th.: 2-4). Dalam hal ini jumbur fuqaha sepakat bahwa nikah itu adalah akad yang diatur oleh agama, untuk memberikan kepada pria hak milik penggunaan terhadap faraj (kemaluan/bagian dari alat reproduksi) perempuan dan seluruh tubuhnya untuk kenikmatan sebagai tujuan primer (alJazairy, J. IV, t.th.: 4).

Adapun definisi pernikahan yang terdapat dalam Undang-undang Pernikahan, UU No. 1 tahun 1974 Pasal 1disebutkan bahwa pernikahan ialah ikatan lahir dan batin antara seorang pria dengan seorang wanita sebagai suami isteri dengan tujuan membentuk keluarga (rumah tangga) yang bahagia dan kekal berdasarkan Ketuhanan Yang Maha Esa”. Definisi ini tidak vulgar namun sarat dengan makna filosofis.

Keluarga bahagia bila dalam keluarga tercipta harmonisasi, dan tidak terjadi kegoncangankegoncangan atau pertengkaran-pertengkaran, sehingga keluarga itu berjalan dengan baik tanpa goncangan atau pertengkaran yang berarti (free from quarelling) (Soekanto, 1990: 98).

\section{Perspektif hukum positif}

Indonesia sebagai negara hukum telah mengatur perkawinan yang tertuang dalam UndangUndang Perkawinan Nomor 1 tahun 1974 tentang perkawinan, dan telah dilengkapi dengan Peraturan Pemerintah Nomer 9 tahun 1975 yaitu tentang pelaksanaan Undang-Undang dan Intruksi Presiden No.1 tahun 1991 tentang Kompilasi Hukum Islam (KHI) dan peraturanperaturan lainnya mengenai perkawinan.

Selama ini perkawinan di bawah tangan (kawin siri) banyak terjadi di Indonesia, baik di kalangan masyarakat biasa, para pejabat ataupun para artis, istilah populernya disebut istri simpanan. Perkawinan di bawah tangan sebenarnya tidak sesuai dengan "maqāsid al-shari'ah", karena ada beberapa tujuan syari'ah yang dihilangkan, sebaimana disebutkan oleh Abdul Gani di antaranya: 
ljtihad, Jurnal Wacana Hukum Islam dan Kemanusiaan, Volume 13, No. 1, Juni 2013: 65-83

Pertama, perkawinan itu harus diumumkan (diketahui khalayak ramai), maksudnya agar orang-orang mengetahui bahwa antara A dengan B telah terikat sebagai suami istri yang sah, sehingga orang lain dilarang untuk melamar A atau B. Akan tetapi dalam perkawinan dibawah tangan selalu di sembunyikan agar tidak di ketahui orang lain, sehingga perkawinan antara A dengan B masih diragukan. Kedua, adanya perlindungan hak untuk wanita, dalam perkawinan di bawah tangan pihak wanita banyak dirugikan hak-haknya, karena kalau terjadi perceraian pihak wanita tidak mendapatkan apa-apa dari mantan suami; Ketiga, untuk maslahah manusia, dalam perkawinan di bawah tangan lebih banyak mudharatnya dari pada maslahatnya. Seperti anak-anak yang lahir dari perkawinan di bawah tangan lebih tidak terurus, sulit untuk bersekolah atau untuk mencari peker aan karena orang tuanya tidak mempunyai Surat nikah dan seandainya ayahnya meninggal dunia/cerai, anak yang lahir dibawah tangan tidak mempunyai kekuatan hukum untuk, menuntut harts warisan dari ayahnya. Keempat, harus mendapat izin dari istri pertama, perkawinan kedua, ke tiga dan seterusnya yang tidak mendapat izin dari istri pertama biasanya dilakukan dibawah tangan, sehingga istri pertama, tidak mengetahui bahwa suaminya,telah menikah lagi dengan wanita lain, rumah tangga seperti ini penuh dengan kebihingan do dusts, karena suami selalu berbohong kepada istri pertama, sehingga perkawinan seperti ini tidak akan mendapat rahmat dari Allah (Gani, 1992: 187-190).

Ketentuan hukum yang mengatur tata cara pernikahan yang dibenarkan oleh hukum adalah UU. No. 1 tahun 1974 tentang pernikahan. Sebelum adanya undang-undang tersebut, hukum yang ada di Indonesia baik pidana dan perdata merupakan hukum warisan pada masa Hindia Belanda. Pada pascakemerdekaan hukum pernikahan di Indonesia bersifat majemuk yang berbeda dari golongan yang satu dengan golongan lainnya (Rasyadi, 1990: 18). Kemajemukan hukum pernikahan akhirnya dapat dihapuskan dengan ditetapkannya UU No. 1 Tahun 1974 tentang pernikahan yang berlaku secara nasional.

Pembangunan bidang hukum di Indonesia dengan ditandai lahirnya UU. No. 1 Tahun 1974 tentang pernikahan, terbitnya Kepres no. 1 Tahun 1991 tentang Kompilasi Hukum Islam (KHI). Lahirnya UU. No. 7 tahun 1989 tentang Peradilan Agama sebagai salah satu badan pelaksana kekuasaan kehakiman yang mandiri dalam menegakkan hukum Islam bagi pencari keadilan yang beragama Islam meliputi perkara-perkara seperti pernikahan, wakaf, hibah, shadaqoh yang telah menjadi hukum positif di tanah air kita (Praja, 1991: 77).

Pelaksanaan UU. No. 1 tahun 1974 tentang pernikahan yang ada di masyarakat masih terdapat penyimpangan. Penyimpangan-penyimpangan disebabkan oleh faktor norma yang berlaku di masyarakat yang telah lama mengakar semenjak Islam berkembang di Indonesia. 
Menurut Juhaya S. Praja hukum Islam yang berlaku di Indonesia dapat dibagi dalam dua bentuk (a) hukum Islam yang berlaku formil yuridis; dan (b) hukum Islam yang berlaku normatif (Praja, 1991: 75).

Pernikahan dapat dikatakan perbuatan hukum dan mempunyai kekuatan hukum, apabila dilakukan menurut ketentuan hukum yang mengatur tata cara pernikahan yang dibenarkan oleh hukum, seperti yang diatur di dalam UU. No. 1 tahun 1974 tentang Perkawinan. Perkawinan yang sesuai dengan un-dang-undang ini mempunyai akibat hukum, mendapat pengakuan, dan perlindungan hukum.

Pasal 2 ayat (2) undang-undang No. 1 tahun 1974, menyatakan bahwa tiap-tiap pernikahan dicatat menurut peraturan perundang-undangan yang berlaku. Pada ayat tersebut tidak dijelaskan tujuan diadakan pencatatan itu. Tapi dalam penjelesan umum undang-undang itu tersirat tujuan diadakannya pencatatan peristiwa-peristiwa penting dalam kehidupan seseorang, misalnya; kelahiran, kematian yang dinyatakan dengan surat keterangan.

Pencatatan perkawinan merupakan suatu akta resmi yang juga dimuat dalam daftar pencatatan. Dalam hal ini HIR Pasal 1863 menyatakan bahwa catatan atau bukti tertulis termasuk alat bukti yang diakui keabsahannya, tidak saja dalam akad nikah, tetapi juga dalam segala bentuk perjanjian perikatan. Pernikahan adalah suatu perbuatan hukum yang memerlukan kepastian hukum. Dalam Pasal 2 ayat (2) disebutkan bahwa:

"Tiap-tiap pernikahan dicacat menurut peraturan perundang-undang yang berlaku. Isi Pasal itu dirumuskan secara organik oleh Pasal 2 ayat (1) PP. No. 9 tahun 1975 bahwa pencatat pernikahan dari mereka yang melangsungkan pernikahannya menurut agama Islam dilakukan oleh pegawai pencatat sebagaimana dimaksudkan UU. No. 32 tahun 1954 tentang Pencatatan Nikah Talak dan Rujuk. Tata cara pencatatan pernikahan dilakukan menurut Pasal 3 dan Pasal 9 PP No. 9 tahun 1975 yang mengatur prosedur pemberitahuan kehendak nikah dan kelengkapan administrasinya kepada Pegawai Pencatat Nikah (PPN). Dalam Pasal 10 ayat (3) dinyatakanh bahwa dengan mengindahkan tata cara pernikahan menurut masingmasing agamanya itu, pernikahan dilaksanakan di hadapan pegawai pencatat dan dihadiri oleh 2 orang saksi. Dalam hal ini, bagi pernikahan yang dilakukan menurut hukum Islam, maka pernikahan harus dilakukan di hadapan PPN" (Zuhdi, 1996: 15-16).

Pencatatan pernikahan bertujuan mewujudkan ketertiban pernikahan dalam masyarakat. Hal ini dilakukan sebagai satu upaya yang diatur melalui undang-undang untuk melindungi martabat dan kesucian pernikahan (Rofiq, 1995:107). Pencatatan nikah asalnya hanya sebuah 
ljtihad, Jurnal Wacana Hukum Islam dan Kemanusiaan, Volume 13, No. 1, Juni 2013:65-83

kebutuhan administrasi negara. Dalam tinjauan sosiologis fungsi dari pencatatan nikah sangat penting khususnya bagi perempuan, berkaitan dengan status anak, dan hak waris yakni hak yang berkaitan masalah harta, serta hak gono-gini. Bagi anak setatus anak, hak waris dan hak perwalian.

Hukum asal pencatatan nikah adalah mubah, akan tetapi eksistensinya menjadi sangat krusial, maka beralihlah hukum mubah itu menjadi wajib. Dalam kaidah fiqbiyah disebutkan; "mātā yatimmu al-wäjib illa bibi fahuwa wäjib" (Hasballah, 1996: 160). Perintah wajib tidak akan sempurna kecuali dengan keberadaannya, maka ia menjadi wajib. Dalam Pasal 11

ayat (l) dinyatakan bahwa sesaat sesudah dilangsungkannya pernikahan sesuai dengan ketentuan- ketentuan Pasal 10 PP ini kedua mempelai menandatangani akta pernikahan yang telah disiapkan oleh pegawai pencatat berdasarkan ketentuan yang berlaku. Pasal 11 ayat (3) menyatakan bahwa dengan penandatanganan akta pernikahan, maka pernikahan tersebut tercatat secara resmi menurut hukum dan kepada masing- masing suami isteri diberi salinan akta nikah. Dengan demikian pernikahan ini dinyatakan sebagai pernikahan yang dilindungi oleh hukum.

Ditinjau dari segi hukum pernikahan yang ada di dalam KHI yang diundangkan dengan Inpres No. 1 tahun 1991 dan Keputusan Menteri Agama No. 154 tahun 1991, hal ini disebutkan dalam Pasal 4, bahwa :

"Pernikahan adalah sah apabila dilakukan menurut hukum Islam sesuai dengan Pasal 2 ayat (1) UU. No. 1 tahun 1974. Pasal 5 ayat (1) menyatakan bahwa agar terjamin ketertiban pernikahan bagi masyarakat Islam setiap pernikahan harus dicatat. Sementara itu pernikahan yang dilakukan di luar ketentuan perundang-undang yang berlaku (dilakukan di luar pengawasan PPN) tidak mempunyai kekuatan hukum (Pasal 6 ayat (2). Dalam Pasal 7 ayat (1) ditegaskan bahwa pernikahan hanya dapat dibuktikan dengan akta nikah yang dibuat oleh PPN" (Saefullah dkk., 2005: 45-46).

Pernikahan yang dilakukan di luar ketentuan perundang-undangan yang berlaku di Negara Republik Indonesia tidak mempunyai kekuatan hukum. Seperti pernikahan di bawah tangan, kawin sirri, atau kawin kyai, pernikahan yang hanya dilakukan menurut hukum agama (Islam) saja, tanpa mengindahkan perundang-undangan yang berlaku, seperti tanpa pencatatan pernikahan oleh PPN sehingga tidak bisa dibuktikan dengan akta autentik (akta nikab). Dengan demikian, pernikahan di bawab tangan hanya sah secara hukum agama tetapi belum mempunyai kekuatan hukum karena belum dicatat (Zen, 2004: 36-46). 
Nikah di bawah tangan menimbulkan permasalah yang kontradiktif. Menurut agama nikah di bawah tangan sah dan menimbulkan beberapa akibat hukum, di antaranya suami wajib memberi mahar, nafkah lahir (makan, pakaian, dan tempat tinggal) dan nafkah batin, istri wajib taat kepada suami, adanya hak saling mewarisi antara suami dan isteri, adanya hubungan nasab anak dengan bapaknya (Zuhaili, 1991: 112-116). Menurut hukum positif pernikahan di bawah tangan tidak mempunyai akibat hukum karena tidak memenuhi Pasal 2 ayat (2) UU. No. 1 tahun 1974.

Persoalan mendasar pernikahan di bawah tangan adalah tak terpenuhinya ketentuan Pasal 2 ayat (2) UU. No. 1 tahun 1974, yaitu unsur pencatatan pernikahan. Menurut pendapat yang lebih kuat, baik dari segi hukum Islam maupun hukum positif, sahnya pernikahan apabila dilangsungkan menurut ketentuan Islam di hadapan PPN, dan dicatat oleh PPN (Marjono: 21, Gani, 1995: 33-51). Lebih lanjut Masyfuk Zuhdi dalam Mimbar Hukum No. 28 thn, VII; 1996 menyatakan berikut ini.

"Pencatatan pernikahan merupakan syarat sah pernikahan yang didasarkan pada 2 hal. Pertama dalil syar'i (agama), yaitu mentaati perintah agama dan mentaati perintah Negara/ pemerintah adalah wajib firman Allah Q.S al-Nisa': 59. Perintah al-Qur'an ini sangat positif karena mendidik manusia untuk menciptakan masyarakat yang sadar dan taat hukum agama dan hukum negara demi terwujudnya kesejahteraan dan kebahagiaan hidup di dunia adan akhirat. Akta nikah sebagai bukti autentik sahnya pernikahan seseorang sangat bermanfaat bagi dirinya dan keluarganya, yaitu isteri dan anaknya untuk menolak kemungkinan di kemudian hari adanya pengingkaran atas pernikahannya itu, dan akibat hukum dari pernikahannya itu, yaitu harta bersama dalam pernikahan, status anak dalam pernikahan dan hak kewarisannya juga untuk melindungi dari fitnah dan tuduhan zina. Dengan demikian pencatatan nikah untuk mendapatkan akta nikah sangat penting sebagai tindakan preventif dan kemasalahatan. Kedua, didasarkan pada alasan yuridis dari segi hukum positif, yaitu maksud Pasal 2 ayat (2) UU. Np. 1 tahun 1974 itu telah dirumuskan secara organik oleh Pasal 2 ayat (1) PP. No. 9 tahun 1975 tentang pelaksanan Undangundang Pernikahan. Tata cara pencatatan pernikahan lebih lanjut dijabarkan pada Pasal 3 sampai 9 PP. No. 9 tahun 1975. Tata cara pernikahan sampai mendapatkan akta nikah disebut dalam Pasal 10 sampai dengan Pasal 13 PP No. 9 tahun 1975. KHI yang diundangkan dengan Inpres. No.1h. 1991, Pasal 5, 6 dan 7 ayat (1) menguatkan bahwa unsur pencatatan nikah oleh PPN menjadi syarat sahnya nikah. 
ljtihad, Jurnal Wacana Hukum Islam dan Kemanusiaan, Volume 13, No. 1, Juni 2013:65-83

\section{Pengertian nikah di bawah tangan}

Pernikahan di bawah tangan adalah bentuk pernikahan yang terjadi dan dilakukan oleh masyarakat. Dalam tinjauan sosiologis ada tiga tipe praktek nikah di bawah tangan atau nikah sirri: Pertama; nikah sirri/ nikah di bawah tangan adalah nikah yang dilaksanakan mengikiuti ketentuan syari'at Islam (telah terpenuhinya syarat dan rukun nikah), hanya saja masih bersifat intern keluarga, belum dilakukan pencatatan oleh Pegawai Pencatat Nikah (PPN) (Hasan, 2006: 297), dan juga belum diadakan perhelatan menurut adat (walimah al'arush). Model pertama ini suami isteri masih tinggal di rumag orang tua masing-masing, karena isteri masih anak-anak usianya belum mencapai ketentuan undang-undang laki-laki usia 19 tahun perempuan usia 16 tahun. Motif model pertama ini untuk menjaga ketenangan, serta batasan halal dan haram dalam pergaulan.

Kedua, nikah sirri dilakukan sesuai dengan ketentuan syari'at Islam, dan telah dicatat oleh perugas PPN, hanya saja belum diadakan perhelatan secara adat, terbuka. Hal ini dilakukan karena suami isteri, atau salah satunya masih sedang menyelesaikan studi. Motif model kedua ini mengharap ketenangan dan menjaga kehalalan pergaulan kedua belah pihak (Tabloid Modus Aceh, 28 April 2009).

Ketiga, nikah sirri yang hanya dilangsungkan menurut syari'at Islam, atau dirahasiakan sengaja dilakukan secara diam-diam. Hal ini berbenturan dengan PP Nomor 10/1983. Perkawinan dan perceraian bagi Pegawai Negeri sipil dan PP Nomor 45/1990, tentang perubahan PP 10/1983. Model ketiga ini, calon suami menghindari hukuman jabatan atas pelanggaran PP tersebut (Zuhdi, 1996: 9).

Menurut analisis penulis Pernikahan model pertama dan kedua adalah sah, sedangkan model ketiga, tidak sah karena hanya mengikuti gejolak nafsu birahi saja, dan banyak mengadung mendorong madarat, bahaya yang besar terutama bagi suami untuk melakukan tindak pidana korupsi.

\section{Pernikahan dalam tinjauan sosiologis}

Tinjauan sosiologis dalam penelitian ini digunakan terhadap pernikahan di bawah tangan yang di lakukan oleh masyarakat muslim di Indonesia. Pada umumnya nikah di bawah tangan di Indonesia dipicu oleh empat faktor, yaitu: Pertama, berbenturan dengan aturan 
hukum positif. Pernikahan di bawah tangan dilakukan untuk menghindari birokrasi yang berbelit-belit dan mungkin sulit untuk dilakukan (Nelson, 2006). Problem tersebut dapat dilihat dalam empat kondisi, yaitu: syah karena terpenuhinya aturan per undang-undangan yang berlaku. 1). Pernikahan campuran yakni pernikahan antara dua orang yang berbeda warganegaranya. Hal ini memerlukan persyaratan administrasi yang cukup rumit, karena melibatkan hukum kedua negara, khususnya pengurusan kewarganegaraan yang bersangkutan. 2). Tidak memiliki status resmi sebagai warganegara (tidak memiliki KTP). Kasus ini terjadi bagi para urban kelompok marginal yang hidup di kota-kota besar. 3). Terkait aturan, seperti PNS wanita tidak boleh menjadi istri kedua, ketiga dan keempat (PP 10/1983 junto PP 45/ 1990). 4). Terkait peraturan sekolah, misalnya masih tercatat sebagai pelajar sekolah menengah, ataupun yang lain (Salamah, Http:/ / nursyam sunan-ampel.ac.id.).

Kedua, faktor psikologis. Nikah di bawah tangan dilakukan karena faktor psikologis dapat terjadi pada seseorang yang usianya telah memenuhi persyaratan, secara ekonomi tidak masalah, tetapi kendalanya masih menyelesaikan studi (kuliah/mondok). Untuk menghindari perbuatan dosa maka dinikahkan di bawah tangan. Biasanya dengan membuat perjanjian yang disepakati kedua belah pihak. Seperti; tidak kumpul sebagai suami istri, tidak memiliki anak dalam jangka waktu yang telah ditentukan.

Ketiga, faktor ekonomi. Nikah di bawah tangan yang disebabkan faktor ekonomi dapat terjadi seperti di daerah-daerah yang ada tenaga kerja asing yang berpenghasilan lebih dari cukup dibanding dengan penduduk asli. Perempuan setempat menikah tanpa catatan untuk mendapatkan sumber ekonomi yang layak (Kahmad, 2010: 32). Demikian pula menjadi kendala ekonomi bagi laki-laki yang kurang mampu untuk mengurus biaya administrasi pencatatan pernikahan pada petugas yang cukup mahal.

Keempat, faktor tradisi. Tradisi yang dilakukan turun temurun yang menganggap nikah di bawah tangan sebagai "kelaziman", praktis dan ekonomis, sehingga tidak butuh legal formal hukum. Ini terjadi pada masyarakat yang masih memegang tradisi leluhur sangat kuat. Seperti pernikahan yang terjadi pada suku Badui dalam di propinsi Banten dan suku-suku yang lain. Di antara ulama atau kyai di berbagai daerah berfatwa sah akad nikah tanpa pencatatan melalui Kantor Urusan Agama. Mereka beralasan bahwa pernikahan di masa Rasulullah saw dan para shahabat tidak pernah dicatat. Akad nikah cukup dilaksanakan dengan izin wali pihak mempelai perempuan dan dihadiri dua orang saksi (Nielson: 2006). 
ljtihad, Jurnal Wacana Hukum Islam dan Kemanusiaan, Volume 13, No. 1, Juni 2013: 65-83

\section{Nikah di bawah tangan dalam tinjauan al-Qur'an dan al-Hadis}

Nikah di bawah tangan dalam pemahaman fikih memiliki arti yang berbeda dengan konteks yang dipahami dalam realitas masyarakat. Dengan kata lain, nikah di bawah tangan adalah nikah yang disembunyikan, dirahasiakan dan tidak diumumkan ke dunia luar (al-Zuhaili, ttp: 71). Dalam hal ini Shafi'iyah dan Hanafiyah menyatakan kebolehannya, Malikiyah membolehkan dalam keadaan darurat (takut terhadap orang atau penguasa yang dhalim), dan Hanbaliyah menyatakan pernikahan di bawah tangan adalah makruh. Sedangkan pengertian nikah dalam pengertian Hukum Islam (Fikih) adalah pernikahan yang dilakukan dua mempelai yang dihadiri wali dan dua saksi dengan upaya disebarluaskan dalam bentuk perayaan/upacara I'lan maupun walimah al-ursh. Nikah dalam konteks fikih juga tidak mensyaratkan adanya pencatatan.

Adapun definisi nikah di bawah tangan dalam pengertian yuridis di Indonesia adalah pernikahan yang dilakukan secara shar'i (konteks fikih) dengan diketahui orang banyak, hanya saja tidak dicatatkan di Kantor Urusan Agama. Sehingga yang membedakan antara nikah di bawah tangan dan bukan adalah Akta Nikah sebagai bukti atas adanya pernikahan (Djubaedah, 2010:345).

Hal yang krusial dalam nikah di bawah tangan adalah tidak terpenuhinya pelaksanaan perundang-undangan yang berlaku di Negara Republik Indonesia, dengan ketentuan sebagai mana yang diutarakan oleh Hasan berikut ini bahwa

"Didasarkan pada alasan yuridis dari segi hukum positif, yaitu maksud Pasal 2 ayat (2) UU. Np. 1 tahun 1974 itu telah dirumuskan secara organik oleh Pasal 2 ayat (1) PP. No. 9 tahun 1975 tentang pelaksanaan Undang-undang Pernikahan. Tata cara pencatatan pernikahan lebih lanjut dijabarkan pada Pasal 3 sampai 9 PP. No. 9 tahun 1975. tata cara pernikahan sampai mendapatkan akta nikah disebut dalam Pasal 10 sampai dengan Pasal 13 PP No. 9 tahun 1975. KHI yang diundangkan dengan Inpres. NO. 1 tahun 1991, Pasal 5, 6 dan 7 ayat (1) menguatkan bahwa unsur pencatatan nikah oleh PPN menjadi syarat sahnya nikah" (Hasan, 2006:298).

Pernikahan di bawah tangan tidak memenuhi pasal 7 ayat (1) tidak mempunyai alat bukti yaitu akta nikah. Dalam pembahasan ini akan dibicarakan kedudukan akta nikah dalam pandangan agama (al-Qur'an dan al-Hadis).

Akta nikah termasuk salah satu alat bukti. Pada Buku keempat bab I, pasal 1865 dan 1866 Kitab Undnag-Undang Hukum Perdata (KUHP) dinyatakan bahwa "setiap orang 
yang mendalilkan bahwa ia mempunyai sesuatu hak, atau guna menegakkan haknya sendiri, maupun membantah suatu hak orang lain, menunjuk kepada suatu peristiwa diwajibkan membuktikan adanya hak atau peristiwa tersebut. Dari pasal ini dipahami bahwa suami isteri yang melaksanakan nikah di bawah tangan perkaranya tidak dapat diselesaikan oleh Peradilan Indonesia, baik Pengadilan Negeri atau Pengadilan Agama maupun pengadilan lainnya, karena pernikahannya tidak mempunyai alat bukti yaitu akta pernikahan yang sah.

"Pasal 1865 undang-undang tersebut, menyatakan bahwa tujuan diadakan alat bukti ialah: (1) Sebagai dalil bahwa seorang mempunyai suatu bukti, (2) untuk meneguhkan dan menguatkan bahwa seseorang mempunyai suatu bukti, (3) untuk membantah atau menyatakan ketidakbenaran bahwa orang lain mempunyai hak, (4) untuk menunjukkan dan menyatakan bahwa telah terdapat suatu keadaan atau telah terjadi suatu peristiwa; Pasal 1866 menyatakan bahwa alat bukti itu ialah: (1) bukti lisan, (2) bukti dengan saksi, (3) pengakuan (4) persangkaan-persangkaan, (5) sumpah- sumpah. Dalam pasal 295 HIR (Het Heziene Indlansch Reglemen) dinyatakan bahwa alat-alat bukti yang sah ialah; (1) Persaksian, (2) surat- menyurat, (3) pengakuan, dan (4) petunjuk-petunjuk".

Dalam tinjauan hukum Islam yaitu Ilmu Fiqih, perkataan yang hampir sama pengertiannya dengan alat-alat bukti ialah “al-bayyinah”, sesuatu dengan pernyataan Ibnu Qayyim “al-Bayyinab” dalam istilah agama lebih umum pengertiannya dibandingkan dengan persaksian.

Dalam hal ini Sayid Sabiq menyebutkan; “turuq al-ithbat” yang terdiri dari: (1) Iqrar, (2) Syahadah, (3) Sumpah, dan (4) Surat-surat resmi (Sabiq, 1998: 58). Bertitik tolak dari uraian tersebut di atas muncul permasalahan: Sejauh mana al-Qur'an dan al-Hadis mensikapi akta pernikahan, atau dengan kata lain adakah keharusan pencatatan suatu pernikahan? Dan bagaimana pula pendapat shahabat dan ulama dalam masalah ini? Al-Qur'an menyebutkan akad nikah adalah sebagai perjanjian yang kuat tidak disamakan dengan perjanjian biasa. (QS. al-Nisa/ 4:21). Allah swt. menerangkan bahwa perjanjian (termasuk akad nikah) yang adil dan benar adalah perjanjian yang dilengkapi dengan alat bukti. Alat Bukti yang terutama ialah alat bukti dengan pencatatan. Allah swt. berfirman:

"Hai orang-orang yang beriman, apabila kamu bermu'amalah tidak secara tunai untuk waktu yang ditentukan, hendaklah kamu menuliskannya. Dan hendaklah seorang penulis diantara kamu menuliskannya dengan benar. Dan janganlah penulis enggan menuliskannya sebagaimana Allah telah mengajarkannya, maka hendaklah ia menulis, dan hendaklah orang yang berhutang itu mengamlakkan (apa yang akan ditulis itu), dan hendaklah ia 
ljtihad, Jurnal Wacana Hukum Islam dan Kemanusiaan, Volume 13, No. 1, Juni 2013:65-83

bertaqwa kepada Allah Tuhannya, dan janganlah ia mengurangi sedikitpun daripada hutangnya” (QS. al-Baqarah/ 2:282).

Bertitik tolak dari dua ayat tersebut di atas dapat dipahamkan bahwa pencatatan atau alat bukti tertulis, termasuk salah satu alat bukti, bahkan pada ayat 282 Surat al-Baqarah disebut sebagai alat bukti primer. Diterangkan bahwa alat bukti tertulis itu lebih adil dan benar di sisi Allah dan lebih dapat menguatkan persaksian serta menghilangkan keraguraguan. Kemudian dinyatakan lagi bahwa bukti tertulis itu selalu dilaksanakan pada perdagangan baik yang tunai ataupun yang tidak tunai. Dapat disamakan kepada perdagangan yang tidak tunai ialah semua perjanjian perikatan yang ada kelanjutannya, tidak selesai persoalan pada saat terjadi persengketaan. Dengan adanya alat bukti yang diyakini keabsahannya oleh semua pihak, baik pihak-pihak yang berakad atau pihak ketiga maupun pihak pemerintah terutama pengadilan.

Sebagaimana uraian tersebut di atas bahwa bukti tertulis itu diperlukan pada semua akad mu'amalah. Akad nikah dapat diqiyaskan pada akad mu'amalah dengan landasan qiyas. Bahkan akad nikah itu adalah perjanjian yang kuat "mîthâq al-galida"(QS. al-Nisa/ 4:21).

Jika pada akad mu'amalah diperlukan bukti tertulis tentulah pada akad nikah bukti tertulis lebih diperlukan. Pada akad mu'amalah yang diakadkan ialah tentang hak atas barang, sedangkan pada akad nikah yang diakadkan itu adalah orang atau diri sendiri yang diikat dengan tali pernikahan dengan diri orang lain. Diri (orang) lebih utama dari barang. Akibat akad nikah akan menimbulkan hak dan kewajiban bukan saja antara suami dan isteri, tetapi juga antara suami isteri dengan anak-anak, bahkan cucu dan keluarganya. Bahkan, setelah suami atau isteri meninggal dunia hak dan kewajiban dari keturunan dan keluarganya masih berlanjut.

Masalah wasiat pun dapat disamakan dengan akad nikah, alat bukti tertulis itu harus ada sebelum dua malam, berdasarkan sabda Nabi Muhammad saw. yang dikutip dari CD Hadis Kutub al-Tis'ah, Buhari no. 2333, Muslim no. 3074, Nasa'i, no.3557, Abi Dawud, no. 2478, Tirmidzi, no. 896, Ibnu Majah, no. 2690, Ahmad, no. 4667.

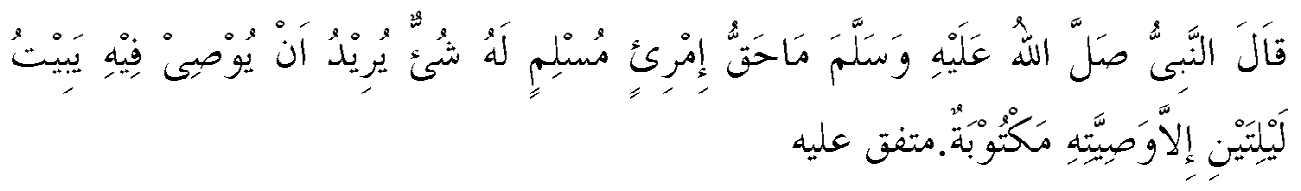


"Bersabda Nabi saw. "tidak ada hak seorang Muslim yang bermaksud mewasiatkan sesuatu yang ada padanya sampai dua malam (atau lebih) kecuali wasiatnya itu ada padanya dalam keadaan tertulis" (Muttafaq 'Alaib).

Bukti secara historis, dan sosiologis, dalam setiap momen yang penting Rasulullah, baik sebagai seorang rasul Allah maupun sebagai kepala pemerintahan, selalu menyiapkan buktibukti tertulis agar bukti-bukti itu dapat dijadikan alat untuk mernyelesaikan hal-hal penting dikemudian hari. Contohnya:

Pertama, Setiap Rasulullah menerima wahyu, beliau menyuruh shahabat untuk mencatat atau menulis wahyu tersebut (al-Shabuni, 1987: 85). Ayat al-Qur'an yang telah ditulis itu selalu beliau uji kesahihannya pada waktu yang telah ditentukan, untuk mengetahui apakah para penulis wahyu itu telah menulis dengan benar sesuai dengan ayat-ayat yang di turunkan kepada beliau. Kedua, Rasulullah saw. selalu mengadakan bukti tertulis pada setiap mengadakan perjanjian damai dengan orang Quraisy (perjanjian Khudaibiyah) dan perjanjian dengan raja-raja yang berada di sekitar jazirah Arab. Demikian pula mengadakan bukti tertulis perjanjian dengan orang- orang Yahudi di Madinah. Alat bukti tertulis telah disepakati penggunaannya dan telah ada dalam dunia pemerintahan, perdagangan/ usaha, peradilan dan sebagainya. Sayid Sabiq menyatakan "Tatkala orang-orang telah membiasakan penggunaan surat-surat berharga dan mereka berpegang dengannya, maka sebahagian ulama mutakhirin mmenerima tuliasan sebagai alat bukti dan beramal dengannya "lebih lanjut beliau menyatakan". demikian pula menerima surat-surat resmi sebagai alat bukti, yaitu surat-surat itu tidak mempunyai unsur-unsur kebohongan dan kebinasaan" (al-Dzahabi, tt: 68).

Berkaitan dengan bukti tertulis Imam Ibnu Qayyim berpendapat "Allah swt. telah menjadikan tulisan setiap penulis berbeda dengan penulis yang lainnya, seperti berbeda bentuk dan suaranya serta kebenarannya. Maka hal ini merupakan landasan pengetahuan untuk mengetahui tulisan pemberita dan membedakan antara satu dengan yang lain (al-Dhahabi, tt: 68). Dalam hal ini jumhur ulama telah mempercayai perawi berdasarkan tulisannya dan tulisan itu diperbolehkan untuk menyampaikannya (meriwayatkannya). Jika hal ini tidak diperbolehkan mempercayai berita yang ditulis perawi, tentulah akan sia-sia al-Hadits dan hukum-hukum fikih yang berlandaskan kutipan atau tulisan yang telah disampaikan mereka (Badrah, tt.: 56).

Mencermati proses penetapan undang-undang No. 1 tahun 1974, tentang pernikahan di Indonesia, berkaitan dengan bukti tertulis yang berupa pencatatan pernikahan telah disepakati 
ljtihad, Jurnal Wacana Hukum Islam dan Kemanusiaan, Volume 13, No. 1, Juni 2013:65-83

keharusannya oleh para ulama Indonesia. Kesepakatan ini telah dapat dimasukkan sebagai ijma, dan kalau ada sebagian kecil yang tidak sependapat namun tidak menunjukkan reaksi penolakan maka dapat dikatagorikan ijma sukuti.

Dari tinjauan hadits Nabi keber-adaan nikah di bawah tangan tidak mempunyai landasan sebab beberapa hadis Nabi yang berhubungan dengan pernikahan Rasul senantiasa menganjurkan: Pertama, mengumumkan pernikahan (Ibnu Majah, hadis No:1885 Ahmad, hadith No: 15545). Kedua, ketidaksukaan Nabi terhadap nikah yang dirahasiakan (Ahmad, hadith no: 16113). Ketiga, anjuran mengadakan walimah (perayaan pernikahan) (Bukhari hadith No. 4771).

\section{Kedudukan wanita yang melakukan nikah di bawah tangan}

Hukum positif Indonesia tentang pernikahan telah berlaku secara nasional sejak tahun 1975, sehingga sampai saat sekarang ini telah berjalan tiga dekade 31 tahun. Jika dilihat dari segi hukum pernikahan di dalam KHI yang diundangkan dengan Inpres No. tahun 1991 dan keputusan Menteri Agama No. 154 tahun 1991 disebutkan dalam pasal 4, bahwa pernikahan adalah sah apabila dilakukan menurut hukum Islam sesuai dengan pasal 2 ayat (1) UU No. 1 tahun 1974. Pasal 5 ayat (1), Pasal 6 ayat (2) dan Pasal 7 ayat (1). Pernikahan yang memenuhi peraturan perundang- undangan yang belaku tersebut sah dan mempunyai kekuatan hukum bagi; suami, istri anak-anak yang dilahirkan, juga harta benda yang diperoleh selama pernikahan, harta bersama (gono-gini) serta hak waris dan segala aspeknya seperti yang disampaikan oleh Nugroho berikut ini.

Persoalan mendasar yang dihadapi pihak perempuan dalam kasus kawin di bawah tangan adalah tidak terpenuhinya ketentuan pasal 2 ayat (2) UU. No. 1 tahun 1974, yaitu pencatatan pernikahan yang berakibat tidak mendapatkan Akta Nikah sebagai bukti autentik sahnya pernikahan. Dalam hal ini istri tidak mempunyai kekuatan hukum di hadapan pengadilan, sehingga akan kehilangan hak untuk dirinya, dan anaknya. Lebih parah lagi jika pihak suami mengingkari atas pernikahan, di bawah tangan tersebut. Maka yang dirugikan adalah pihak perempuan dan berdampak kepada anaknya, karena tidak terpenuhinya UU No. 1 tahun 1974 pasal 2 ayat (2), anak yang dilahirkan dari pernikahan itu secara resmi tidak terdaftar kelahirannya pada Kantor Catatan Sipil (tidak mendapatkan akta kelahiran) sebagai anak sah dari pihak ayah, disebabkan tidak adanya akta nikah. Pencatatan kelahiran adalah hak dasar setiap anak dan merupakan perlindungan pertama terhadap hak dan 
status anak, karena merupakan pengakuan negara yang pertama dalam status hukum (Nugroho, 2007).

Dalam kasus nikah di bawah tangan, cerai gugat yang diajukan oleh pihak perempuan (istri) pada umumnya pihak suami cenderung mengingkari telah terjadi pernikahan di bawah tangan antara keduanya (Kasus Macica yang melahirkan Putusan Mahkamah Konstitusi No. 46/PUU-VIII/2010. Tanggal 17 pebruari 2012).

Istilah nikah di bawah tangan merupakan istilah khas Indonesia pada peristiwa perkawinan yang tidak dicatatkan. Pada masa Rasulullah saw maupun sahabat belum dikenal adanya pencatatan perkawinan. Jangankan pada masa Rasul, zaman buyut dan kakek kita pun pencatatan belum dianggap penting. Namun tinjauan sosiologis pada zaman Nabi, perkawinan sah apabila telah memenenuhi syarat dan rukunnya, dan harus diketahui serta diumumkan untuk diketahui warga masyarakat, pernikahan pun di'ilankan, diumumkan kepada khalayak luas, antara lain melalui media walimah al-'ursh (al-Bassam, 2006: 309).

Bila terjadi perselisihan atau pengingkaran telah terjadinya perkawinan, pembuktiannya cukup dengan alat bukti persaksian. Berkait dengan pengumuman ini Nabi saw bersabda: Umumkanlah pernikahan dan pukullah rebana (HR. Ibnu Majah). Dalam hadith lain Nabi juga bersabda: Adakanlah walimah (perhelatan) meskipun hanya dengan memotong seekor kambing (HR. al-Bukhari).

Akan tetapi karena perubahan dan tuntutan zaman serta demi pertimbangan kemaslahatan, di beberapa negara muslim, termasuk di Indonesia, telah dibuat aturan yang mengatur perkawinan dan pencatatannya. Dikandung maksud demi tertib hukum dan masyarakat, perkawinan dalam masyarakat, adanya kekuatan hukum, dan untuk melindungi pihak-pihak yang melakukan perkawinan itu sendiri serta akibat dari terjadinya perkawinan, seperti nafkah isteri, hubungan orang tua dengan anak, kewarisan, dan lain-lain (Nugraha, 2007).

Perubahan hukum, khususnya berkait dengan pencatatan perkawinan dinilai penting mengingat perkembangan dan tuntutan zaman yang mengandaikan berbagai keteraturan dalam hal-hal kependudukan dan administrasi Negara. Perubahan hukum semacam ini adalah sah sesuai dengan kaidah fiqhiyah yang berbunyi:

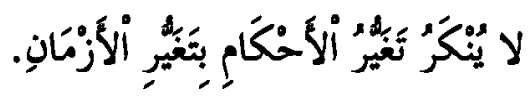

Artinya: Tidak diingkari perubahan hukum karena perubahan zaman. 
ljtihad, Jurnal Wacana Hukum Islam dan Kemanusiaan, Volume 13, No. 1, Juni 2013: 65-83

Ibnu al-Qayyim menyatakan "Perubahan fatwa dan perbedaannya terjadi menurut perubahan zaman, tempat, keadaan, niat dan adat istiadat" (al-Jauzi, J. VII, tt: 3).

Pada dasarnya, fungsi pencatatan pernikahan adalah agar seseorang memiliki alat bukti (bayyinah) untuk membuktikan bahwa dirinya benar-benar telah melakukan pernikahan dengan orang lain. Sebab, salah bukti yang dianggap absah sebagai bukti syar'iy (bayyinah shar'iyyah) adalah dokumen resmi yang dikeluarkan oleh negara. Ketika pernikahan dicatatkan pada lembaga yang berwenang, tentunya seseorang telah punya sebuah dokumen resmi yang bisa ia dijadikan sebagai alat bukti (bayyinah) di muka majelis peradilan, ketika ada sengketa yang berkaitan dengan pernikahan, maupun sengketa yang lahir akibat pernikahan, seperti waris, hak asuh anak, perceraian, nafkah, dan lain sebagainya.

Di samping itu, pencatatan perkawinan selain substansinya untuk mewujudkan ketertiban hukum juga mempunyai manfaat preventif, seperti supaya tidak terjadi penyimpangan rukun dan syarat perkawinan, baik menurut ketentuan agama maupun peraturan perundangundangan. Tidak terjadi perkawinan antara laki-laki dan perempuan yang antara keduanya dilarang melakukan akad nikah. Meng-hindarkan terjadinya pemalsuan identitas para pihak yang akan kawin, seperti laki-laki yang mengaku jejaka tetapi sebenarnya dia mempunyai isteri dan anak. Tindakan preventif ini dalam peraturan perundangan direalisasikan dalam bentuk penelitian persyaratan perkawinan oleh PPN, seperti yang diatur dalam Pasal 6 PP Nomor 9 Tahun 1975.

Keharusan mencatatkan perkawinan dan pembuatan akta perkawinan, dalam hukum Islam, diqiyaskan kepada pencatatan dalam persoalan mudāyanah yang dalam situasi tertentu diperintahkan untuk mencatatnya, seperti disebutkan dalam firman Allah surat al-Baqarah ayat 282: yang artinya: Hai orang-orang yang beriman, apabila kamu bermu'amalah tidak secara tunai untuk waktu yang ditentukan, hendaklah kamu menuliskannya. al-(QS. al-Baqarah /2: 282).

Apabila akad hutang piutang atau hubungan kerja yang lain harus dicatatkan, mestinya akad nikah yang begitu luhur, agung, dan sakral lebih utama lagi untuk dicatatkan. Berdasarkan mafhum muwafaqat dari ayat tersebut dapat dipahami bahwa tranksaksi utang-piutang saja disyariatkan untuk dituliskan, tentu akan lebih penting lagi mencatatkan akad (tranksaksi) yang mengikat kehidupan dua insan dalam bentuk perkawinan. 
Apalagi, perkawinan merupakan akad yang yang sangat kuat (mithäq al-galida) Qiyas tersebut dalam istilah ushul fikih disebut qiyas al-aulawi (analogi yang hukum nya pada furu' lebih kuat daripada yang melekat pada asalnya). Pencatatan perkawinan yang diwajibkan oleh negara nyatanya mengantarkan tercapainya kemaslahatan bagi kehidupan warganegara. Penetapan hukum atas dasar kemaslahatan merupakan salah satu prinsip dalam penetapan hukum Islam, sebagaimana disebutkan dalam qaidah: Artinya: Suatu tindakan pemerintah berintikan terjaminnya kepentingan dan kemaslahatan rakyatnya (Jazuli, 2003: 83).

Maka bagi setiap muslim-muslimah, para pemuda/i, yang telah mampu menikah, menikahlah Carilah pasangan yang terbaik, untuk mewujudkan kebahagiaan dunia akhirat. Catatkan pernikahannya pada lembaga yang berwenang yaitu di KUA.

\section{Penutup}

Berdasarkan uraian tersebut di atas dapat disimpulkan sebagai berikut: Pertama, pencatatan suatu pernikahan menurut undang-undang yang berlaku di Negara Indonesia termasuk salah satu asas disahkannya pernikahan.

Kedua, pernikahan yang tercatat pada lembaga resmi pemerintah sesuai dengan perundangundangan yang berlaku lebih banyak maslahat-nya bagi umat Islam, sedang pernikahan yang tidak tercatat lebih banyak mafsadah- nya. Nikah di bawah tangan sah secara syar'i akan tetapi tidak mempunyai kepastian hukum, hal ini menimbulkan implikasi negatif yang cukup besar, yakni: (a) tidak adanya jaminan kepastian hukum bagi pihak yang berrelasi, istri tidak bisa menggugat suami apabila ditinggalkan oleh suami; (b) secara ekonomis, sosial, kultur, psikologis, dan hukum, posisi perempuan lebih lemah, karena keberpihakan berbagai aturan yang patriarkhi; (c) adanya pihak yang dirugikan, karena tidak jelas status dan masa depannya. Anak hasil perkawinan di bawah tangan tidak memiliki status, seperti akta kelahiran, tidak menerima warisan. Istri tidak mendapat waris dan tunjangan apapun jika suami meninggal dunia.

Ketiga, pencatatan nikah bukan merupakan syarat dan rukun akad nikah, akan tetapi ia dapat menyempurnakan pelaksanaan hak dan kewajiban yang ditimbulkan oleh akad nikah, dan dapat menepis implikasi negatif yang ditimbulkan dalam kehidupan sosial kemasyarakatan, khususnya bagi perempuan dan anak. 
ljtihad, Jurnal Wacana Hukum Islam dan Kemanusiaan, Volume 13, No. 1, Juni 2013: 65-83

\section{Daftar pustaka}

al-Bassam, Abdullah bin Abdurahman. Sharh Bulüg al-Maräm. Cet, I, Jakarta: Pustaka Azzam, 2006.

al-Jazairy, Abdurrahman. al-Fiqh 'ala-Madhāhib al-Arba'ah. Beirut: Dār al-Fikr, jilid IV. ttp. al-Maraghi, Abdullah. Al-Zawāj wa al-'alāq Fi Jamī'i al-Adyān. Kairo: Dār al-Turāth alIslāmiyah, 1966.

al-Dhahabi, Muhammad Husein. al-Shari'ah al-Istamiyyah. Kairo: Dār al-Qur'an, t.th.

al-Zuhaili, Wahbah. al-Fiqh al-Islämi wa Adillatuh. Beirut: Dār al- Fikr, 1991.

ash-Shabuni, Muhammad Ali. Pengantar Studi Al-Qur'an (al-Tibyān). Alih Bahasa oleh Moch Chudlori Umar dan Moh. Matsna, Bandung: al-Ma'arif, 1987.

ash-Shiddiqi, Hasbi. Al-Qur'an dan Terjemahnya. Jakarta: PT. Intermasa, 1995.

Azra, Azyumardi. "the Indonesian Marriage Law of 1974: Institutionalization of Sharia for Sosial Changes” dalam Azzumardi Azra \& Arskal Salim dalam Sharia and Politics in Modern Indonesia. Singapore: Institute of Southest Asean Studies, 2003.

Badrah, Abdul. 'Ainain, Al-Zawāj wa al-'alaq fi al-Isläm. Kairo: Dar al-Qur'an, t.th.

Direktorat Jendral Pembinaan Kelembagaan Agama Islam. Ushul Fiqh II. Jakarta: DEPAG, 1996.

Direktorat Pembinaan Badan Peradilan Agama, Direktorat Jendral Pembinaan Kelembagaan Agama Islam, Departemen Agama RI. Kompilasi Hukum Islam (KHI) di Indonesia. Jakarta: DEPAG, 1999/2000.

Djazuli, A. Fiqh Siyasah, edisi revisi, Bogor: Kencana, 2003.

Djubaedah, Neng. Pencatatan Perkawinan \& Perkawinan Tidak Dicatat Menurut Hukum Tertulis di Indonesia dan Hukum Islam. Jakarta: Sinar Grafika, 2010.

Gani, Abdullah A. Tinjauan Hukum terhadap Pernikahan di bawah tangan. dalam Mimbar Hukum. Jakarta: Pustaka Akbar, No, 23, Tahun VI. 1995.

Hartono, Mardjono. “Syarat Manakah yang Menentukan Sahnya Pernikahan?” dalam Mimbar Hukum. Jakarta: Pustaka Akbar, No. 23. Tahun VI, 1995.

Hasan, M. Ali, Pedoman Hidup Rumah Tangga dalam Islam, Jakarta: Seroja Prenada Media Group, 2006.

Hasballah, Ali. Ușūl al-Tashrì' al-Islami. Kuwait: Dār al-Ma'àrif, t.th.

Kahmad, Dadang. 'Nikah Sirri dalam Pandangan Kaum Intelektual di Kota Bandung”'Hasil Penelitian di UIN Sunan Gunung Jati Bandung, 2010.

Kartasapoetra, G. dkk. Sosiologi Umum. Jakarta: Bina Aksara, 1997.

Mubarak, Jaih. Qawaìd al-Fiqhiyyah. Bandung: Remaja Rosdakarya, 2004. 
Nugroho, Anjar. "Nikah Mut'ah dan Nikah Sirr : Bedah Pemikiran Daud Rashid”. Forum Diskusi. September 2007.

Praja, Juhaya S. Hukum Islam di Indonesia Pemikiran dan Praktek. Bandung: Remaja Rosdakarya, 1991.

Rahman, Bakri A. dan A. Sukardja. Hukum Pernikahan Menurut Islam, Undang-undang Pernikahan dan Hukum Perdata/ BW. Jakarta: PT.Hidakarya Agung, 1981.

Rasadi, Lili. Pernikahan dan Perceraian. Jakarta: Bina Aksara, 1990.

Rofiq, Ahmad. Hukum Islam di Indonesia. Jakarta: Rajawali Press, 1995.

Sabiq, Sayid. Fiqh al-Sunnah. Beirut: Dār al-Kutub al-'Arabī, 1991.

Saefullah, Muhammad, dkk. Hukum Islam Solusi Permasalahan Keluarga. cet. Ke I, Yogyakarta: UII Press, 2005.

Salamah, Husniyatus. Hasil Penelitian di Desa Rembang, Pasuruan Jawa Timur. Hhtp:// nursyam sunan-ampel.ac.id/.

Tim Redaksi Tanwirulafkar, Ma’had Aly PP Salafiyah Situbondo. Fikih Rakyat Pertautan Fikih dengan Kekuasaan. cet. Ke I, Yogyakarta: LKIS, 2000.

Zen, Satria Efendi M. Problema tentang Hukum Keluarga Islam Kontemporer (Analisis Yurisprudensi dengan Pendekatan Usul Fikih), Jakarta: Prenada Media, 2004.

Zuhdi, Masyfuk. Nikah di bawah tangan dan Status Anaknya Menurut Hukum Islam dan Hukum Positif dalam Mimbar Hukum. Jakarta: Pustaka Akbar, No. 28 Tahun VII, 1996.

Tabloid Modus Aceh edisi 52 tahun VI, 28 April 2009.

CD Hadis Kutub al-Tis'ah. Hadis Buhari no. 2333, Muslim no. 3074, Nasa'i no. 3557, Abi Dawud no. 2478, al-Tirmidzi no. 896, Ibnu Majah no. 2690 dan imam Ahmad no. 4667. 